\title{
Comparative Evaluation of Success of Biodentine and Mineral Trioxide Aggregate with Formocresol as Pulpotomy Medicaments in Primary Molars: An In Vivo Study
}

\author{
Shilpa Ahuja ${ }^{1}$, Kumari Surabhi ${ }^{2}$, Kapil Gandhi ${ }^{3}$, Rishabh Kapoor ${ }^{4}$, Ritika Malhotra ${ }^{5}$, Dipanshu Kumar ${ }^{6}$
}

\begin{abstract}
Aim: The study was designed to evaluate and compare the success of Biodentine and mineral trioxide aggregate (MTA) in comparison to formocresol as pulpotomy medicaments over 9 months of the follow-up period.

Materials and methods: The sample of 60 deciduous molars of patients aged 4-7 years were incorporated in the study. The molars were randomly allocated to the experimental and control groups. Following coronal pulp removal and achieving hemostasis, the radicular pulp was covered with either Biodentine or MTA (experimental groups). In the control group, a cotton pellet soaked with diluted formocresol (one-fifth dilution of Buckley's formocresol) was placed over the radicular pulp for 1 minute. All pulpotomized molars were later restored with stainless steel crowns (SSCs).

Results: The achieved clinical success over 9 months of the follow-up period was 100, 95, and 70\% with Biodentine, MTA, and formocresol, respectively. The achieved radiographic success over 9 months of the follow-up period was 95, 60, and 25\% with Biodentine, MTA, and formocresol, respectively.

Conclusion: Favorable biological, physical, mechanical, and good manipulation properties of Biodentine show that this material can be used efficiently as a pulpotomy medicament in the clinical practice.

Keywords: Biodentine, Deciduous molars, Formocresol, Mineral trioxide aggregate, Pulpotomy.

International Journal of Clinical Pediatric Dentistry (2020): 10.5005/jp-journals-10005-1740
\end{abstract}

\section{INTRODUCTION}

A vital pulp therapy procedure aims to retain the health and integrity of a tooth, its supporting periodontium, and preserves the integrity of the arch. One such therapeutic technique that is being used to prevent a carious primary tooth from extraction is pulpotomy, which is performed in the tooth having deep caries with no associated indication of any radicular pulpitis. This technique employs the removal of the affected coronal pulp, while preserving the vital radicular pulp.,

As per the medicament used, the pulpotomy procedure has been classified by Ranly into three types, i.e., devitalization, preservation, and regeneration. ${ }^{3}$

Formocresol (Buckley, 1904) is still regarded as the "gold standard" pulpotomy medicament. Irrespective of the many disadvantages like cytotoxicity, pulp inflammation, necrosis, systemic disturbances, mutagenicity, carcinogenic potential, and immunological responses, ${ }^{4}$ it is the most widely used pulpotomy medicament over the decades with a huge success rate, owing to its bacteriostatic and fixative properties.

Searching for more biocompatible pulpotomy agents, the mineral trioxide aggregate (MTA) was introduced by Torabinejad in mid-1990s as a novel material for the pulpotomy procedure in both primary and permanent teeth. ${ }^{5,6}$ The MTA offers properties like excellent biocompatibility, promotes tissue regeneration, and provides a good marginal integrity with no microleakage. However, there are some disadvantages like difficult manipulation, long setting time, high $\mathrm{pH}$, short shelf life, causes discoloration of teeth, and low compressive strength. ${ }^{7-12}$

Biodentine (Septodont, St. Maur-Des-Fosses, France), a newer bioactive cement, has been shown to be useful in numerous
${ }^{1-6}$ Department of Pedodontics and Preventive Dentistry, Inderprastha Dental College and Hospital, Ghaziabad, Uttar Pradesh, India

Corresponding Author: Kapil Gandhi, Department of Pedodontics and Preventive Dentistry, Inderprastha Dental College and Hospital, Ghaziabad, Uttar Pradesh, India, Phone: +91 9811311377, e-mail: drkapilgandhi@gmail.com

How to cite this article: Ahuja S, Surabhi K, Gandhi K, et al. Comparative Evaluation of Success of Biodentine and Mineral Trioxide Aggregate with Formocresol as Pulpotomy Medicaments in Primary Molars: An In Vivo Study. Int J Clin Pediatr Dent 2020;13(2):167-173.

Source of support: Nil

Conflict of interest: None

clinical applications such as pulp capping, pulpotomy, and a pexification. ${ }^{13,14}$

Biodentine is a bioactive cement with mechanical properties similar to the dentin, hence it can be used as a dentin substitute. Placement of Biodentine over a health pulpal tissue has been shown to encourage reparative dentin formation. It is biocompatible, has short setting time, long shelf life, high compressive strength, and better handling properties. ${ }^{13-15}$

The literature review shows limited clinical trials with Biodentine as a pulpotomy agent. ${ }^{15-18}$ Published results have shown Biodentine and MTA as potential substitutes for the currently employed pulpotomy medicaments.

Therefore, the present study aimed at evaluating and comparing the success of Biodentine and MTA in comparison to formocresol as pulpotomy medicaments over 9 months of the follow-up period. 


\section{Materials and Methods}

The study was conducted on 60 deciduous molars in patients aged 4-7 years visiting the outpatient department of pedodontics and preventive dentistry. Prior to initiation of the study, ethical approval was obtained by the institutional review board with IRB no. $2015 / 2138$ A.

Only primary molars indicated for pulpotomy were admitted to the study. The inclusion criteria included only healthy cooperative patients with no account of spontaneous or persistent pain in selected teeth. The selected tooth should have lost more than one-third of the marginal ridge due to caries and should be with absence of the abscess and intraoral sinus. The tooth should be restorable, with deep dentinal caries approximating the pulp or iatrogenic exposure of the pulp, diagnosed as reversible pulpitis and on excavating the pulp from the pulp chamber, the color of the blood from the pulp should be bright red and bleeding should stop within 2-3 minutes after application of a moist cotton pellet.

The radiographic inclusion criteria that were taken into considerations were presence of two-third of the root of primary molars, no evidence of inflammatory internal/external resorption of roots, and no evidence of interradicular bone loss or bifurcation or trifurcation radiolucency.

The exclusion criteria included teeth with the history of continuous pain on lying down, acute irreversible pulpitis, presence of a swelling or a sinus tract in relation to the carious tooth, exfoliating tooth, and presence of pathological mobility. Radiographically, presence of furcation and interradicular radiolucency indicating bone loss, evidence of pathological internal/external resorption of roots due to inflammation, and physiological or inflammatory root resorption more than one-third were also excluded from the study.

\section{Methodology}

A detailed history was documented from each patient/guardian followed by a thorough examination both clinically and radiographically. The technique and its possible merits and demerits were described to the guardians and their informed consent was secured.

A total of 80 primary molars were evaluated clinically and radiographed preoperatively and only those fulfilling the inclusion selection criteria were included in the study. The pulpotomy procedure was performed on the 60 selected primary molars. Selected primary molars were allocated to three groups by means of systemic randomization according to pulp medicaments used. Group I-Biodentine group (BD), group II-MTA group, and group III-formocresol group (FC) consisted of 20 teeth each, respectively. Groups I and II were experimental groups, and group III was kept as a control group. Following local anesthetic administration and rubber dam application, the caries were removed and access was made with a No. 330 bur to expose and deroof the coronal pulp chamber. Pulp amputation was done with a sterile spoon excavator and irrigation with normal saline to remove any debris present. Hemostasis was achieved with sterile moistened cotton pellets. After arrest of bleeding, following steps were taken:

In the Biodentine group, prior to opening a Biodentine capsule, a gentle tapping was done. For mixing the powder, five drops of liquid were dispensed into the capsule. The capsule was triturated for 30 seconds. The material was recovered with a sterile cement spatula and placed onto the amputated radicular pulp with a sterile amalgam carrier. A dry cotton pellet was used to condense the material without excessive pressure on radicular pulp stumps.

In the MTA group, the MTA was manipulated in the ratio of 3:1 (powder:liquid) to obtain a putty mix. This mix was placed over the radicular pulp with the help of a suitable sterile amalgam carrier. Gentle condensation of the mix was done in the pulp chamber with a moistened cotton pellet.

In the formocresol group, one-fifth dilution of Buckley's formocresol (moistened cotton pellet) was placed for 1 minute on the amputated radicular pulp stumps. The chamber was them flushed with normal saline to remove all the traces of the formocresol liquid. After drying the chamber, zinc oxide eugenol cement was condensed over the fixed radicular pulp stumps.

Each tooth was sealed using the glass ionomer cement. An immediate postoperative radiograph was taken. Each patient was recalled after 2 days to check clinically for any discomfort. Final restoration was done with placement of a stainless steel crown (SSC). Clinical and radiographic evaluation after 3, 6, and 9 months was done for each patient. To assess the success of the procedure, the following clinical and radiographic criteria were taken into consideration. Clinically, absence or presence of pain, tenderness on percussion, inflammatory swelling, tooth mobility, and presence of fistula or sinus were documented. Radiographically, presence or absence of radiolucency in periapical or furcation area, pathological external or internal resorption of the root, widening of the periodontal space, and calcification of the radicular canal were recorded.

\section{Statistical Analysis}

SPSS version 21.0 and Epi-info version 3.0 were used. The Chi-square test was employed to assess whether distributions of categorical variables differ from one another. The $p$ value was observed at a $95 \%$ confidence interval $(\mathrm{Cl})$ and was marked to be significant when less than $0.05(p<0.05)$.

\section{Observations and Results}

Initially, a total of 80 primary molars needing pulpotomy as a treatment procedure were included in the study in view of the possible dropouts from the study. Out of 80 teeth, 60 teeth that had complete follow-up records were included for statistical evaluation and comparison.

When comparison was made between Biodentine, MTA, and formocresol for the clinical success rate at 3,6, or 9 months' interval, it was found that at the end of 9 months, the clinical success rate was 100,95 , and $70 \%$ with Biodentine, MTA, and formocresol, respectively.

At the end of 9 months, six (30\%) cases developed failures in the FC group and one (5\%) case developed failure in the MTA group. The higher success rate was found in Biodentine in comparison to formocresol and MTA. Statistically significant difference was observed in the clinical success rate at 9 months' interval between BD, MTA, and FC groups with $p$ value of 0.007 (Table 1 and Fig. 1).

When comparison was made between Biodentine, MTA, and formocresol for the radiographic success rate at 3, 6, or 9 months' interval, it was found that at the end of 9 months the radiographic success rate was 95, 60, and 25\% with Biodentine, MTA, and formocresol, respectively.

A total of 1 (5\%), 15 (75\%), and 8 (40\%) cases developed failures in BD, FC, and MTA groups, respectively. Statistically significant difference was observed in the radiographic success rate at 6 and 
Table 1: Clinical evaluation of Biodentine and formocresol and MTA as pulpotomy agents

\begin{tabular}{|c|c|c|c|c|c|c|}
\hline Clinical success & & $B D(\%)$ & $F C(\%)$ & MTA (\%) & Chi-square value & $p$ value \\
\hline \multirow[t]{4}{*}{3 months } & Success & 20 & 20 & 20 & 0.000 & 1.000 \\
\hline & & 100.0 & 100.0 & 100.0 & & \\
\hline & Total & 20 & 20 & 20 & & \\
\hline & & 100.0 & 100.0 & 100.0 & & \\
\hline \multirow[t]{6}{*}{6 months } & Success & 20 & 18 & 19 & 2.105 & 0.349 \\
\hline & & 100.0 & 90.0 & 95.0 & & \\
\hline & Failure & 0 & 2 & 1 & & \\
\hline & & 0.0 & 10.0 & 5.0 & & \\
\hline & Total & 20 & 20 & 20 & & \\
\hline & & 100.0 & 100.0 & 100.0 & & \\
\hline \multirow[t]{6}{*}{9 months } & Success & 20 & 14 & 19 & 10.027 & $0.007^{*}$ \\
\hline & & 100.0 & 70.0 & 95.0 & & \\
\hline & Failure & 0 & 6 & 1 & & \\
\hline & & 0.0 & 30.0 & 5.0 & & \\
\hline & Total & 20 & 20 & 20 & & \\
\hline & & 100.0 & 100.0 & 100.0 & & \\
\hline
\end{tabular}

*Significant difference

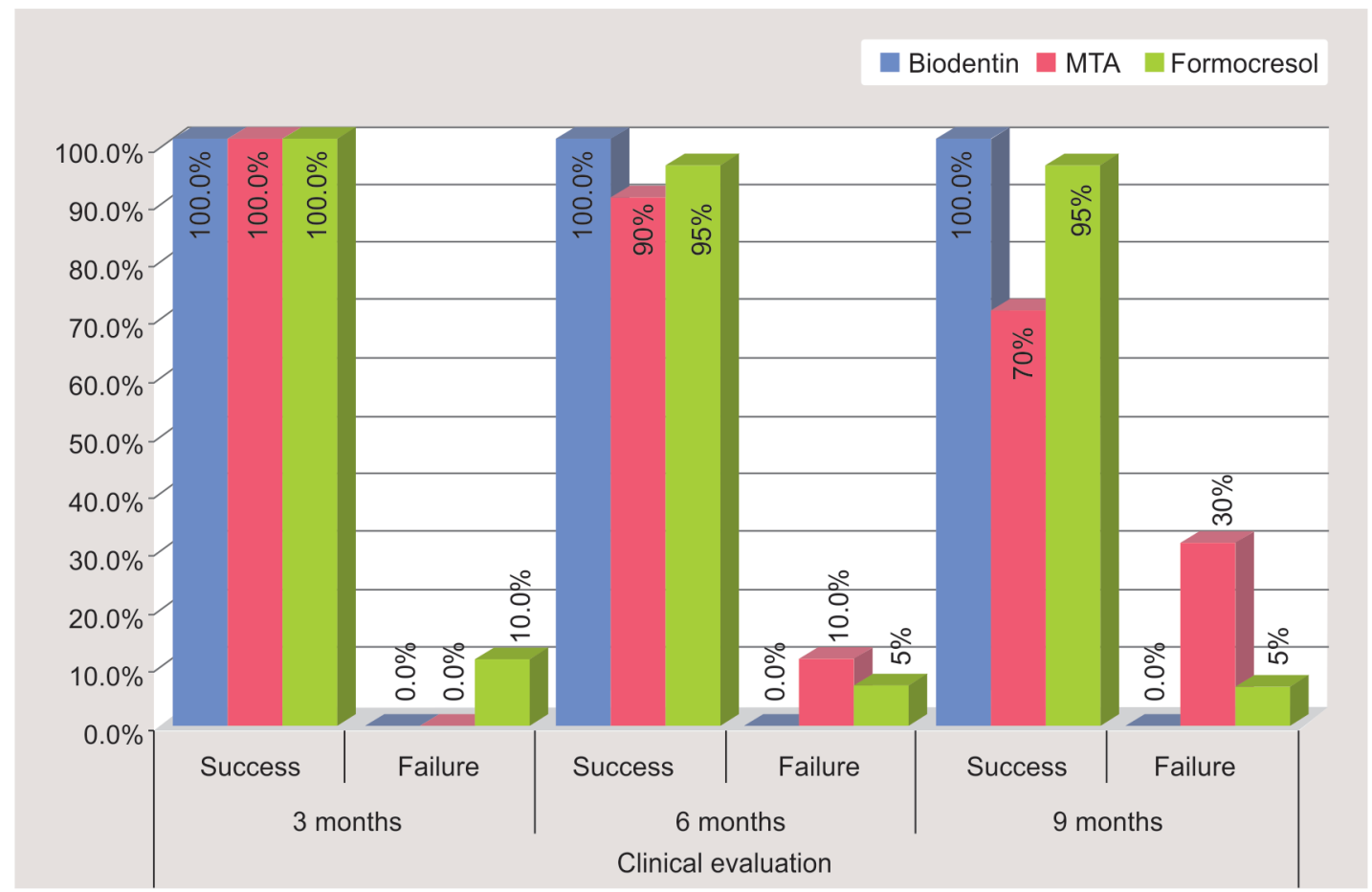

Fig. 1: Clinical evaluation of Biodentine and formocresol and MTA as pulpotomy agents

9 months between BD, MTA, and FC groups with a higher success rate in the BD group with the $p$ value of 0.038 at 6 months and 0.011 at 9 months (Table 2 and Fig. 2).

\section{Discussion}

A randomized, controlled clinical study was performed for evaluating and comparing the success of Biodentine and MTA with formocresol as the pulpotomy medicament with definite clinical and radiographic inclusion and exclusion criteria.

The study was conducted on children aged 4-7 years. Children with deeply carious vital deciduous molars indicated for pulpotomy were selected for the study. The limited cooperation of younger patients and physiologic root resorption (more than two-third of the root length) in older ones were considered while selecting the age group. To draw a definite conclusion, 9 months' follow-up was taken into consideration.

Post pulpotomy, all teeth were restored with SSC. This was done to provide a long-term restoration as it has been observed that after pulpotomy, an effective restoration may impact the prognosis of pulp therapy. ${ }^{5}$

An intraoral periapical radiographic evidence was recorded and preserved for each tooth immediately postoperatively to assess the 
Table 2: Radiographic evaluation of Biodentine and formocresol and MTA as pulpotomy agents

\begin{tabular}{|c|c|c|c|c|c|c|}
\hline \multicolumn{2}{|c|}{ Radiographic success } & \multirow{2}{*}{$\frac{B D(\%)}{20}$} & \multirow{2}{*}{$\frac{F C(\%)}{19}$} & \multirow{2}{*}{$\frac{\text { MTA (\%) }}{20}$} & \multirow{2}{*}{$\frac{\text { Chi-square value }}{1.034}$} & \multirow{2}{*}{$\frac{p \text { value }}{0.542}$} \\
\hline 3 months & Success & & & & & \\
\hline & & 100.0 & 95.0 & 100.0 & & \\
\hline & Failure & 0 & 1 & 0 & & \\
\hline & & 0.0 & 5.0 & 0.0 & & \\
\hline & Total & 20 & 20 & 20 & & \\
\hline & & 100.0 & 100.0 & 100.0 & & \\
\hline \multirow[t]{6}{*}{6 months } & Success & 20 & 14 & 18 & 5.210 & $0.038^{*}$ \\
\hline & & 100.0 & 70.0 & 90.0 & & \\
\hline & Failure & 0 & 6 & 2 & & \\
\hline & & 0.0 & 30.0 & 10.0 & & \\
\hline & Total & 20 & 20 & 20 & & \\
\hline & & 100.0 & 100.0 & 100.0 & & \\
\hline \multirow[t]{6}{*}{9 months } & Success & 19 & 5 & 12 & 10.237 & $0.011^{*}$ \\
\hline & & 95.0 & 25.0 & 60.0 & & \\
\hline & Failure & 1 & 15 & 8 & & \\
\hline & & 5.0 & 75.0 & 40.0 & & \\
\hline & Total & 20 & 20 & 20 & & \\
\hline & & 100.0 & 100.0 & 100.0 & & \\
\hline
\end{tabular}

*Significant difference

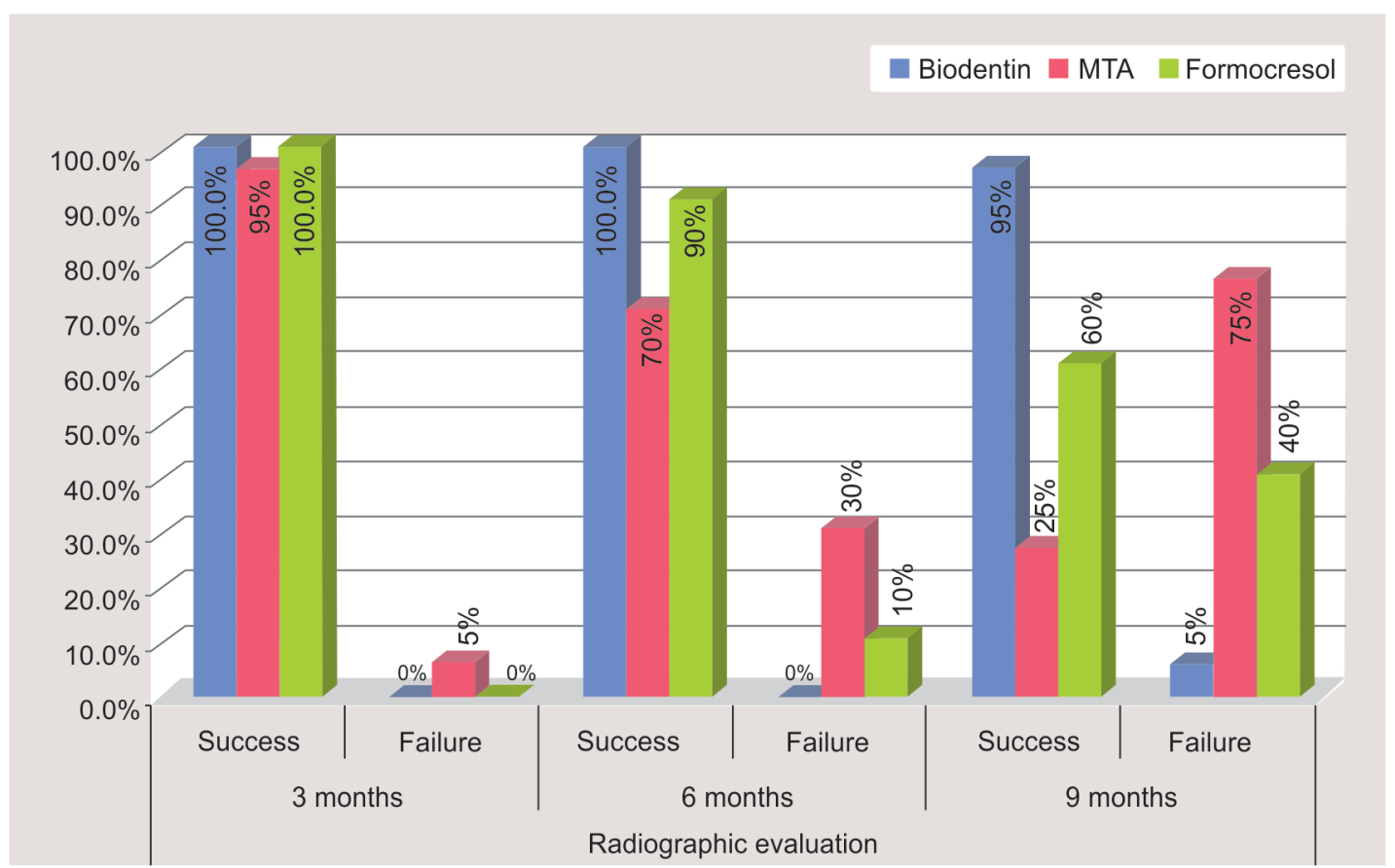

Fig. 2: Radiographic evaluation of Biodentine and formocresol and MTA as pulpotomy agents

quality of pulp therapy performed and set as baseline for follow-up comparisons. Post pulpotomy, failures are mostly observed in the furcation and periapical areas, therefore intraoral periapical radiographs were the radiographs of choice for evaluation of interand periradicular radiographic changes.

Dentine bridge formation was not evaluated in the present study, as the radiopaque metal in the stainless steel crown (SSC) could have masked any bridge formed.

No tooth was extracted after pulpotomy (successful/failed) for the purpose of histological examination. All the samples were evaluated clinically and radiographically over 9 months (with 3 months' interval follow-up).

The current study assessed clinical success rate at 3,6, and 9 months' interval; it was found that at the end of 9 months, the clinical success rate was 100, 95 , and $70 \%$ with Biodentine, MTA, and formocresol, respectively.

Moreover, when radiographic assessment was done at 3, 6, and 9 months' interval, it was found that at the end of 9 months, the radiographic success rate was 95,60 , and $25 \%$ with Biodentine, MTA, and formocresol, respectively. This observation was in 
accordance with many studies by various researchers, which are mentioned herein for their relevant factors and possible treatment success outcomes. In an in vivo study conducted by Rubanenko et al., they observed $100 \%$ success with Biodentine whereas $94 \%$ with formocresol as pulpotomy medicament. ${ }^{15}$ Cuadros et al. demonstrated Biodentine as a viable alternative pulpotomy medicament in deciduous molars with up to $100 \%$ success clinically and radiographically over a period of 6 months. ${ }^{16}$ Niranjani et al. performed pulpotomies with MTA, laser, and Biodentine and observed comparable efficiency clinically/radiographically. ${ }^{19}$ However, contrary to the results obtained in the present study and to those by the other researchers, a study done by Juneja et al. reported a radiographic success rate of $100 \%$ for MTA and $86.6 \%$ for the Biodentine group. ${ }^{20}$

This high success of Biodentine in several reports can be attributed to its physical properties like good marginal adaptation, high biocompatibility, sealing capability, and stimulating tissue regeneration. ${ }^{15}$ These promising results of Biodentine have been investigated by various authors. About et al. studied the interaction of Biodentine with pulp progenitor cells and concluded that Biodentine induces odontoblast differentiation. ${ }^{21}$ Zanini et al. assessed the biological effect of Biodentine and reported that it can be considered as an appropriate medicament for the regeneration of the pulp-dentin complex. ${ }^{22}$

One of the major limitations observed with MTA throughout the present study was the long setting time of the material. The MTA requires moist conditions to carry out its setting reaction over a long period of approximately 4 hours. Therefore, a moist cotton pellet has to be placed over MTA to set within the cavity. Thus, the cavity is initially sealed with an interim restorative material. Hence, a subsequent visit is required for removal of the leftover cotton pellet and the cavity is sealed with the glass ionomer cement.

However, the superior results obtained for MTA over formocresol in the present study have been similar to the results reported by Agamy et al., which concluded that clinical, radiographical, and histological examination of pulpotomized teeth over a period of 12 months revealed better outcomes with MTA when compared to formocresol. ${ }^{23}$ Furthermore, Stringhini Junior et al. also obtained superior results of MTA over formocresol. ${ }^{24}$ Similarly, in a study by Jayam et al., the authors evaluated the clinical and radiographical success of MTA with formocresol for primary tooth pulpotomy. After 24 months, a success rate of 90.48 and $100 \%$ was observed with formocresol and MTA, respectively. ${ }^{25}$ Attributes like excellent biocompatibility and good marginal seal make MTA superior to formocresol.
In the present study, some failures were reported based on clinical and radiographical criteria. Considering overall clinical failures at the 9 months' follow-up period, no tooth treated with Biodentine reported any signs of clinical failure. Similar results of $100 \%$ clinical success were evaluated by Bharti et al. ${ }^{26}$ About $5 \%$ cases in the MTA group with clinical assessment of intraoral sinus were recorded as clinical failure, whereas $30 \%$ cases in the formocresol group developed mobility and intraoral sinus as sign of clinical infection associated with pulpotomy treatment (Table 3 ). One of the main reasons for failure in the pulpotomized tooth could be the undetected inflamed pulp without any clinical signs of inflammation.

Overall, the radiographic failure rate with Biodentine was $5 \%$, while with MTA it was $40 \%$ and with formocresol it was $75 \%$ at 9 months of the follow-up period. A high rate of radiographic failures of formocresol pulpotomy was obtained as widening of the periodontal space with internal root resorption, furcal/ periapical radiolucency, and external pathological resorption of the root (Table 4). In contrast to these findings, the radiographic failure rate of formocresol according to Ibricevic et al. was $3 \%$ over a period of 20 months' follow-up, ${ }^{9}$ Ansari et al. was $10 \%$ at the end of 24 months. ${ }^{27}$ Internal resorption after formocresol pulpotomy may be due to the continuous irritation from vapours of the liquid that escape via the apical foramen, and also due to the fixative effect of formocresol. Various studies like those of Fuks et al. and Huth et al. have reported similar effects in their studies. ${ }^{28,29}$ The internal resorption noticed in the MTA group may have been due to undetected inflammation present in the radicular portion of the pulp before pulp therapy. ${ }^{30}$ One explanation for external pathological root resorption in formocresol pulpotomy is that the residual formocresol continuously irritates the surrounding periodontium (cell-mediated reaction) and leads to the resorption. ${ }^{20}$ The furcation radiolucency could be due to improper diagnosis of the radicular pulpal status, prior to treatment. Moreover, it has also been observed that due to the small formocresol molecular size, it can sometime seep through the primary root canal or accessory root canals into the surrounding periodontium and might lead to the bone resorption in furcation area. Furcation radiolucency in MTA might be due to the wider pulp canals in younger teeth, which can facilitate the transfer of stimulatory factors. ${ }^{31}$

The results observed from the current study indicate that Biodentine may prove to be a promising pulpotomy medicament with minimal adverse effects. Moreover, with time Biodentine may even substitute formocresol in deciduous molar pulpotomies.

Table 3: Clinical assessment for mobility and intraoral sinus over 9 months of follow-up

\begin{tabular}{|c|c|c|c|c|c|c|}
\hline Mobility & & $B D(\%)$ & $F C(\%)$ & MTA (\%) & Chi-square value & $p$ value \\
\hline 3 months & Absent & 20 & 20 & 20 & 0.000 & 1.000 \\
\hline \multirow[t]{2}{*}{6 months } & Absent & 20 & 17 & 20 & 4.138 & 0.126 \\
\hline & Present & 0 & 3 & 0 & & \\
\hline \multirow[t]{2}{*}{9 months } & Absent & 20 & 15 & 20 & 10.909 & $0.004^{*}$ \\
\hline & Present & 0 & 5 & 0 & & \\
\hline Intraoral sinus & & $B D(\%)$ & $F C(\%)$ & MTA (\%) & Chi-square value & $p$ value \\
\hline 3 months & Absent & 20 & 20 & 20 & 0.000 & 1.000 \\
\hline \multirow[t]{2}{*}{6 months } & Absent & 20 & 20 & 19 & 2.034 & 0.362 \\
\hline & Present & 0 & 0 & 1 & & \\
\hline \multirow[t]{2}{*}{9 months } & Absent & 20 & 18 & 19 & 2.105 & 0.349 \\
\hline & Present & 0 & 2 & 1 & & \\
\hline
\end{tabular}

*Statistically significant 
Table 4: Radiographic assessment for widening of periodontal space, internal resorption, external pathological root resorption, furcal/periapical radiolucency, and abnormal calcification over 9 months of follow-up

\begin{tabular}{|c|c|c|c|c|c|c|}
\hline \multicolumn{2}{|c|}{ Widening of periodontal space } & \multirow{2}{*}{$\frac{B D(\%)}{20}$} & \multirow{2}{*}{$\frac{F C(\%)}{19}$} & \multirow{2}{*}{$\begin{array}{l}\text { MTA (\%) } \\
20\end{array}$} & \multirow{2}{*}{$\frac{\text { Chi-square value }}{2.034}$} & \multirow{2}{*}{$\frac{p \text { value }}{0.362}$} \\
\hline 3 months & Absent & & & & & \\
\hline & Present & 0 & 1 & 0 & & \\
\hline \multirow[t]{2}{*}{6 months } & Absent & 20 & 16 & 20 & 8.571 & $0.014^{*}$ \\
\hline & Present & 0 & 4 & 0 & & \\
\hline \multirow[t]{2}{*}{9 months } & Absent & 20 & 9 & 20 & 26.939 & $0.001^{*}$ \\
\hline & Present & 0 & 11 & 0 & & \\
\hline \multicolumn{2}{|c|}{ Internal resorption } & $B D(\%)$ & $F C(\%)$ & MTA (\%) & Chi-square value & pvalue \\
\hline \multirow[t]{2}{*}{3 months } & Absent & 20 & 19 & 20 & 2.034 & 0.362 \\
\hline & Present & 0 & 1 & 0 & & \\
\hline \multirow[t]{2}{*}{6 months } & Absent & 20 & 16 & 20 & 8.571 & $0.014^{*}$ \\
\hline & Present & 0 & 4 & 0 & & \\
\hline \multirow[t]{2}{*}{9 months } & Absent & 20 & 9 & 16 & 16.533 & $0.001^{*}$ \\
\hline & Present & 0 & 11 & 4 & & \\
\hline \multicolumn{2}{|c|}{$\begin{array}{l}\text { External pathological root resorp- } \\
\text { tion }\end{array}$} & $B D(\%)$ & $F C(\%)$ & MTA (\%) & Chi-square value & $p$ value \\
\hline 3 months & Absent & 20 & 20 & 20 & 0.000 & 1.000 \\
\hline \multirow[t]{2}{*}{6 months } & Absent & 20 & 19 & 20 & 2.034 & 0.362 \\
\hline & Present & 0 & 1 & 0 & & \\
\hline \multirow[t]{2}{*}{9 months } & Absent & 20 & 18 & 20 & 4.138 & 0.026 \\
\hline & Present & 0 & 2 & 0 & & \\
\hline \multicolumn{2}{|c|}{ Furcal/periapical radiolucency } & $B D(\%)$ & $F C(\%)$ & MTA (\%) & Chi-square value & $p$ value \\
\hline \multirow[t]{2}{*}{3 months } & Absent & 20 & 19 & 20 & 2.034 & 0.362 \\
\hline & Present & 0 & 1 & 0 & & \\
\hline \multirow[t]{2}{*}{6 months } & Absent & 20 & 16 & 18 & 4.444 & 0.108 \\
\hline & Present & 0 & 4 & 2 & & \\
\hline \multirow[t]{2}{*}{9 months } & Absent & 19 & 9 & 14 & 11.905 & 0.003 \\
\hline & Present & 1 & 11 & 6 & & \\
\hline \multicolumn{2}{|c|}{ Abnormal calcification } & $B D(\%)$ & $F C(\%)$ & MTA (\%) & Chi-square value & $p$ value \\
\hline 3 months & Absent & 20 & 20 & 20 & 0.000 & 1.000 \\
\hline 6 months & Absent & 20 & 20 & 20 & 0.000 & 1.000 \\
\hline \multirow[t]{2}{*}{9 months } & Absent & 20 & 20 & 19 & 2.034 & 0.362 \\
\hline & Present & 0 & 0 & 1 & & \\
\hline
\end{tabular}

*Statistically significant

Data collected from the present study may provide a platform on which further long-term studies with larger sample size may be designed to evaluate the routine clinical application of Biodentine in the pediatric dental setup.

\section{Conclusion}

Formocresol has been in much debate since the past few years as a pulpotomy medicament. Dentistry all over the world is trying to phase out formocresol from the routine pediatric dental application and is thus searching for novel substitutes that will offer both minimal adverse effects and excellent clinical results. Outcomes from clinical trials using Biodentine and MTA as pulpotomy medicaments have shown promising results when compared to formocresol and may soon be accepted as viable alternatives to formocresol in the pediatric clinical practice.

\section{References}

1. Guideline on pulp therapy for primary and immature permanent teeth. AAPD Reference manual. 2012;33:213-218.

2. Golpayegani MV, Ansari G, Tadayon N, et al. Low-level laser therapy for pulpotomy treatment of primary molars. J Dent 2009;6(4):168-174.

3. Ranly DM. Pulpotomy therapy in primary teeth: new modalities for old rationales. Pediatr Dent 1994;16(6):403-409.

4. Peng L, Ye L, Guo X, et al. Evaluation of formocresol versus ferric sulphate primary molar pulpotomy: a systematic review and meta-analysis. Int Endod J 2007;40(10):751-757. DOI: 10.1111/j.13652591.2007.01288.x.

5. Torabinejad M, Watson TF, Pitt Ford TR. Sealing ability of a mineral trioxide aggregate when used as a root end filling material. J Endod 1993;19(12):591-595. DOI: 10.1016/S0099-2399(06)80271-2.

6. Torabinejad M, Chivian N. Clinical applications of mineral trioxide aggregate. J Endod 1999;25(3):197-205. DOI: 10.1016/S00992399(99)80142-3. 
7. Eidelman E, Holan G, Fuks AB. Mineral trioxide aggregate vs. formocresol in pulpotomized primary molars: a preliminary report. Pediatr Dent 2001;23(1):15-18.

8. Myers DR, ShoafHK, Dirksen TR, et al. Distribution of 14C-formaldehyde after pulpotomy with formocresol. J Am Dent Assoc 1978;96(5):805813. DOI: 10.14219/jada.archive.1978.0187.

9. Ibricevic $\mathrm{H}$, al-Jame Q. Ferric sulfate as pulpotomy agent in primary teeth: twenty month clinical follow-up. J Clin Pediatr Dent 2000;24(4):269-272. DOI: 10.17796/jcpd.24.4.d7u6405nw1132705.

10. Caicedo R, Abbott PV, Alongi DJ, et al. Clinical, radiographic and histological analysis of the effects of mineral trioxide aggregate used in direct pulp capping and pulpotomies of primary teeth. Aust Dent J 2006;51(4):297-305. DOI: 10.1111/j.1834-7819.2006.tb00447.x.

11. Holan G, Eidelman E, Fuks AB. Long-term evaluation of pulpotomy in primary molars using mineral trioxide aggregate or formocresol. Pediatr Dent 2005;27(2):129-136.

12. Salako N, Joseph B, Ritwik P, et al. Comparison of bioactive glass, mineral trioxide aggregate, ferric sulfate, and formocresol as pulpotomy agents in rat molar. Dent Traumatol 2003;19(6):314-320. DOI: 10.1046/j.1600-9657.2003.00204.x.

13. Dammaschke T. A new bioactive cement for direct pulp capping. Int Dent 2012;2(2):64-69.

14. Goupy L. Biodentin: a novel dentine substitute for use in paediatric conservative dentistry. Septodont Case Studies Collection 2012;1: 10-16.

15. Rubanenko M, Moskovitz M, Petel R, et al. Effectiveness of biodentine versus formocresol as dressing agents in pulpotomized primary molars: preliminary results. 12th congress of EAPD, Sopot, Poland 2014.

16. Cuadros C, Garcia J, Sandra S, et al. Clinical and radiographic evaluation of Biodentine and MTA in pulpotomies of primary molars. 12th Congress of EAPD, Sopot 2014.

17. Rajasekharan S, Cauwels R, Vandenbulcke J, et al. Efficacy of 3 pulpotomy medicaments in primary molars - a randomized control trial with one year follow up. 12th Congress of EAPD, Sopot 2014.

18. Lavaud A, Morchid L, Thebaud N, et al. Biodentine ${ }^{\circledR}$, a new dentin substitute: case reports. 11th congress of the EAPD, Strasbourg 2012.

19. Niranjani K, Prasad GM, Vasa AAK, et al. Clinical evaluation of success of primary teeth pulpotomy using mineral trioxide aggregate, laser and Biodentine- an in vivo study. J Clin Diagn Res 2015;9(4): ZC35-ZC37. DOI: 10.7860/JCDR/2015/13153.5823.
20. Juneja P, Kulkarni S. Clinical and radiographic comparison of Biodentine, mineral trioxide aggregate and formocresol as pulpotomy agents in primary molars. Eur Arch Paediatr Dent 2014;19:312-316.

21. About I, Laurent $\mathrm{P}$, Tecles O. Bioactivity of Biodentine: a $\mathrm{Ca}_{3} \mathrm{SiO}_{5}$ based dentin substitute. J Dent Res 2010;89(2):165-169. DOI: $10.1177 / 0022034509358392$.

22. Zanini M, Sautier JM, Berdal A, et al. Biodentine induces immortalized murine pulp cell differentiation into odontoblast-like cells and stimulates biomineralization. J Endod 2012;38(9):1220-1226. DOI: 10.1016/j.joen.2012.04.018.

23. Agamy HA, Bakry NS, Mounir MM, et al. Comparison of mineral trioxide aggregate and formocresol as pulp-capping agents in pulpotomized primary teeth. Pediatr Dent 2004;26(4):302-309.

24. Stringhini Junior E, Vitcel ME, Oliveira LB. Evidence of pulpotomy in primary teeth comparing MTA, calcium hydroxide, ferric sulphate, and electrosurgery with formocresol. Eur Arch Paediatr Dent 2015;16(4):303-312. DOI: 10.1007/s40368-015-0174-z.

25. Jayam C, Mitra M, Mishra J, et al. Evaluation and comparison of white mineral trioxide aggregate and formocresol medicaments in primary tooth pulpotomy: clinical and radiographic study. J Indian Soc Pedod Prev Dent 2014;32(1):13-18. DOI: 10.4103/0970-4388.127043.

26. Bharti K, Kumar R, Khanna R. Clinical and radiographical evaluation of mineral trioxide aggregate, Biodentine and propolis as pulpotomy medicaments in primary teeth. Restor Dent Endod 2015;40(4):276285. DOI: 10.5395/rde.2015.40.4.276.

27. Ansari G, Ranjpour M. Mineral trioxide aggregate and formocresol pulpotomy of primary teeth: a 2-year follow-up. Int Endod J 2010;43(5):413-418. DOI: 10.1111/j.1365-2591.2010.01695.x.

28. Fuks $A B$, Holan $G$, Davis JM, et al. Ferric sulfate versus dilute formocresol in pulpotomised primary molars: long-term follow up. Pediatr Dent 1997;19:327-330.

29. Huth KC, Paschos E, Hajek-Al-Khatar N, et al. Effectiveness of 4 pulpotomy techniques: a randomized controlled trial. J Dent Res 2005;84(12):1144-1148. DOI: 10.1177/154405910508401210.

30. Sonmez D, Sari S, Cetinbas T. A comparison of four pulpotomy techniques in primary molars: a long term follow-up. J Endod 2008;34(8):950-955. DOI: 10.1016/j.joen.2008.05.009.

31. Neamatollahi $\mathrm{H}$, Tajik A. Comparison of clinical and radiographic success rates of pulpotomy in primary molars using formocresol, ferric sulfate and mineral trioxide aggregate (MTA). J Dent 2006;31:6-14. 